\title{
125 I seed irradiation induces apoptosis and inhibits angiogenesis by decreasing HIF-1 $\alpha$ and VEGF expression in lung carcinoma xenografts
}

\author{
GUI-LING XIANG ${ }^{1}$, XIN-HONG ZHU ${ }^{2}$, CUN-ZHI LIN ${ }^{1}$, LI-JUN WANG ${ }^{1}$, \\ YONG SUN $^{1}$, YI-WEI CAO ${ }^{1}$ and FANG-FANG WANG ${ }^{1}$ \\ ${ }^{1}$ Department of Respiratory Medicine, The Affiliated Hospital of Qingdao University, Qingdao, Shandong 266003; \\ ${ }^{2}$ Department of International Clinic, Qingdao Municipal Hospital, Qingdao, Shandong 266071, P.R. China
}

Received September 29, 2016; Accepted March 9, 2017

DOI: 10.3892/or.2017.5521

\begin{abstract}
The purpose of this study was to examine the effects of irradiation by 125I seeds in human lung cancer xenograft model and to determine the underlying mechanisms involved, with a focus on angiogenesis. A group of 40 mice bearing A549 lung adenocarcinoma xenografts was randomly separated into 4 groups: control group $(\mathrm{n}=10)$, sham seed $(0 \mathrm{mCi})$ implant group $(n=10), 125 I$ seed $(0.6 \mathrm{mCi})$ implant group $(\mathrm{n}=10)$ and $125 \mathrm{I}$ seed $(0.8 \mathrm{mCi})$ implant group $(\mathrm{n}=10)$, respectively. The body weight and tumor volume, were recorded every four days until the end of the study. At 30 days after irradiation, the microvessel density, proliferative index and apoptotic index were evaluated by quantitative morphometric analysis of the expression of CD34, proliferating cell nuclear antigen (Ki-67) and in situ terminal transferase-mediated fluorescein deoxyUTP nick-end labeling (TUNEL), respectively. The changes in the expression of hypoxia inducible factor- $1 \alpha(\mathrm{HIF}-1 \alpha)$ and vascular endothelial growth factor (VEGF) were detected by real-time PCR and western blot analysis. Consequently, 125I seed irradiation suppressed the growth of lung cancer xenografts in nude mice, while inhibiting cell proliferation and angiogenesis and inducing apoptosis as demonstrated by Ki67, CD34 and TUNEL staining. HIF-1 $\alpha$ and VEGF mRNA and protein expression levels were substantially downregulated
\end{abstract}

Correspondence to: Professor Cun-Zhi Lin, Department of Respiratory Medicine, The Affiliated Hospital of Qingdao University, Qingdao, Shandong 266003, P.R. China

E-mail: lindoc@126.com

Abbreviations: VEGF, vascular endothelial growth factor; HIF-1 $\alpha$, hypoxia inducible factor-1 $\alpha$; EBRT, external beam irradiation; TUNEL, transferase-mediated fluorescein deoxy-UTP nick-end labeling

Key words: 125I seed irradiation, lung carcinoma, apoptosis, angiogenesis, hypoxia inducible factor- $1 \alpha$, vascular endothelial growth factor following 125I seed irradiation. Collectively, our data suggest that irradiation by $125 \mathrm{I}$ seeds is a promising new option for lung cancer treatment.

\section{Introduction}

Lung cancer is the most common cancer worldwide, and more than 1.8 million new cases and almost 1.6 million deaths were estimated in 2012, with most of these cases (80-85\%) categorized as non-small cell lung cancer (NSCLC) (1). In China, lung cancer is the most frequently diagnosed cancer and the leading cause of cancer-related death (2). NSCLC treatments include surgery, chemotherapy, and radiation therapy, which are determined by the type and stage of cancer. Surgery is the only curative treatment of NSCLC; however, less than $20 \%$ of NSCLC patients who were not diagnosed at advanced stages of the disease are potentially curable with surgical resection (3). Numerous clinical studies have confirmed the effectiveness of chemotherapy combined with external beam irradiation (EBRT) in the treatment of patients with NSCLC presenting with locally advanced malignancy (4-7). To our disappointment, they have not greatly affected outcomes, and the gain often comes with substantial severe toxicity (myelosuppression, nausea, vomiting and radiation pneumonitis), especially affecting important organs and tissues (heart, esophagus, and large blood vessels) $(8,9)$. A great number of patients with advanced NSCLC also cannot tolerate the currently available treatment modalities mainly owing to their poor general condition, especially with other complication. Therefore, novel therapeutic approaches are urgently needed to effectively prolong survival time and obviously improve the quality of life in advanced patients.

In recent years, 125I implantation has been widely used to treat advanced and inoperable prostate cancer, lung cancer, pancreatic cancer, colorectal cancer and head and neck cancer because of accurate positioning, little trauma, high doses in the target volume, few normal tissues exposed and minimal complications (10-14). The advantages of 125I have led to its widespread application in China $(11,15)$.

Although many clinical trials have reported that 125 I seed radiation is a feasible adjuvant treatment to control local 
symptoms and prolong survival for advanced or unresectable NSCLC $(16,17)$, its biological effects and underlying molecular mechanisms are far from fully understood.

$\mathrm{Qu}$ and colleagues (18) demonstrated that a continuous low-dose rate of irradiation (CLDR) induced stronger growth inhibition in A549 cells than single EBRT due to the aggravation of G2/M arrest, and increased apoptosis. Takabayashi and colleagues (19) demonstrated that 125I seed irradiation induced apoptosis and suppressing proliferation in histologically varied gastric cancers to exert antitumor effects. The tumor microenvironment is often hypoxic, and tumor hypoxia is associated with formation of new capillaries and resistance to radiation therapy. HIF (e.g. HIF-1 $\alpha$, HIF-2 $\alpha$, HIF-3 $\alpha$ ) are activated in response to hypoxia, which upregulate numerous genes affecting angiogenesis. VEGF as the best known and the most efficient angiogenic factor is constitutively activated. It is thus inferred that the HIF upregulation of VEGF is most likely responsible for angiogenesis in tumors $(20,21)$. It is well known that angiogenesis is absolutely required for tumor growth. Therefore, inhibition of angiogenesis can prevent tumor growth (22). This study was designed to investigate 125I-induced cell apoptosis, suppressing proliferation and angiogenesis and the possible role of HIF-1 $\alpha$ and VEGF in the process of $125 \mathrm{I}$ brachytherapy in lung carcinoma. Herein, we examined its biological effects on adenocarcinoma cells, the most common pathological type of NSCLC, using xenograft models.

\section{Materials and methods}

Cell line and cell culture. The human lung adenocarcinoma cell line A549 was purchased from the American Type Culture Collection (ATCC, Manassas, VA, USA). The cells were cultured in RPMI-1640 (Gibco, Carlsbad, CA, USA) medium supplemented with $10 \%$ heat-inactivated fetal bovine serum and $1 \%$ pen-strep (100 U/ml penicillin and $100 \mathrm{mg} / \mathrm{ml}$ streptomycin) (Gibco) in a $37^{\circ} \mathrm{C}$ humidified incubator containing $5 \% \mathrm{CO}_{2}$. All experiments were performed using cells grown to $60-80 \%$ confluence. For in vivo injections, suspensions with $>95 \%$ viability were used, as determined by trypan blue exclusion.

Animal model. Female BALB/c nude mice, 4-6 weeks old and weighing 17-20 g, were purchased from Institute of Chinese Academy of Medical Sciences and allowed to acclimatize for 1 week under specific pathogen-free conditions $\left(23 \pm 2^{\circ} \mathrm{C}\right.$ and $55 \pm 5 \%$ humidity) in the Animal Care Facility before any intervention was initiated. The mice were housed and maintained under specific pathogen-free conditions in facilities approved by the Animal Care and Use Committee of Qingdao University School of Medicine. A549 cells $\left(5 \times 10^{6}\right)$ in $0.2 \mathrm{ml}$ PBS were injected subcutaneously into the right dorsal flank of each mouse. Mice were monitored daily for tumor development and total body weight, tumor incidence and mass, were recorded every four days till the end of study. The tumor volume (V) was calculated by the following formula: $\mathrm{V}\left(\mathrm{mm}^{3}\right)=\mathrm{LxW}^{2} \mathrm{x} 1 / 2$ ( $\mathrm{L}$, length of tumor; W, width of tumor).

$125 \mathrm{I}$ seeds. The $125 \mathrm{I}$ seeds were provided by Invasive Technology Department of The Affiliated Hospital of Qingdao University, with a diameter of $0.8 \mathrm{~mm}$, and a length of $4.5 \mathrm{~mm}$.
The average energy was 27.4 to $35.5 \mathrm{keV}$, with a half-life of 59.6 days. After decaying into the organs, the 125I seeds released continuous low-dose $\gamma$-ray and soft X-ray (5\% of $35 \mathrm{keV}$ and $95 \%$ of $28 \mathrm{keV}$, respectively). The internal irradiation was relatively long-acting, 93-97\% of the brachytherapy dose was delivered within 8-10 months.

$125 \mathrm{I}$ brachytherapy seed implant. As tumors reached a size of approximately $300 \mathrm{~mm}^{3}$ in about 24 days, mice were randomly divided into 4 groups ( $n=10 /$ group). Four groups were grouped as follows: non-implanted control group; sham seed implant group; $125 \mathrm{I}$ seed $(0.6 \mathrm{mCi})$ implant group; and $125 \mathrm{I}$ seed $(0.8 \mathrm{mCi})$ implant group. Before in vivo implantation, each mouse was anesthetized via inhalation of diethyl ether (provided by Pharmacy Department of the Affiliated Hospital of Qingdao University). The visible mass in mice was punctured by the 18-gauge needles of the Mick-applicator through which seeds were implanted. After 30 days of treatment, all mice were humanely sacrificed, and tumors were harvested and weighed, then fixed in $4 \%$ paraformaldehyde (PFA) or flash frozen in liquid nitrogen.

Immunohistochemistry for Ki67 and CD34. Immunohistochemical procedures of Ki67 and CD34 were done as described previously by Lee and colleagues (23). In brief, samples of the tumors were fixed in $4 \%$ PFA for $24 \mathrm{~h}$, embedded with paraffin, then sectioned $(4 \mu \mathrm{m})$ longitudinally and stained with hematoxylin and eosin (H\&E). Following staining cell proliferation and microvessel density was assessed by quantitative morphometric analysis of Ki67 and CD34 expression, respectively. For detecting CD34 and Ki67 immunoreactivity, tissue sections were deparaffinized with sequential washing of xylene, rehydrated with descending grades of ethanol, followed by antigen retrieval and endogenous peroxidase treatment. After blocking endogenous peroxides and nonspecific proteins, sections were incubated at $4^{\circ} \mathrm{C}$ overnight with rabbit anti-mouse monoclonal anti-Ki67 antibody (Abcam, Cambridge, MA, USA) at a 1:100 dilution and rabbit anti-mouse monoclonal anti-CD34 antibody (Cell Signaling Technology, Boston, MA, USA) at a 1:85 dilution, respectively. Subsequently, slides were washed three times in Tris-buffered saline (TBS), and incubated for $20 \mathrm{~min}$ at room temperature with peroxidase-conjugated goat antirabbit IgG secondary antibodies (Abcam). Negative controls were incubated with PBS instead of the primary antibody. Visualization was achieved with a diaminobenzidine (DAB) substrate system in which nuclei with DNA fragmentation or endothelial cells were stained brown.

TUNEL staining. For the detection of apoptosis, tumor specimens were subjected to a TUNEL assay using the In Situ Cell Death Detection kit (Roche, Basel, Switzerland), in accordance with the manufacturer's instructions. Briefly, 4\% PFA fixed tissues were permeabilized with Proteinase $\mathrm{K}$ working solution (provided in the kit) at $37^{\circ} \mathrm{C}$ for $30 \mathrm{~min}$. The slides were washed twice in PBS and incubated with $50 \mu \mathrm{l}$ of TUNEL reaction mixture (provided in the kit) in a dark and humid atmosphere for $60 \mathrm{~min}$ at $37^{\circ} \mathrm{C}$, followed by incubation with Converter-POD solution (provided in the kit) for $30 \mathrm{~min}$ at $37^{\circ} \mathrm{C}$. Slides were developed using DAB, mounted under glass coverslip, and then analyzed under a light microscope. 
A

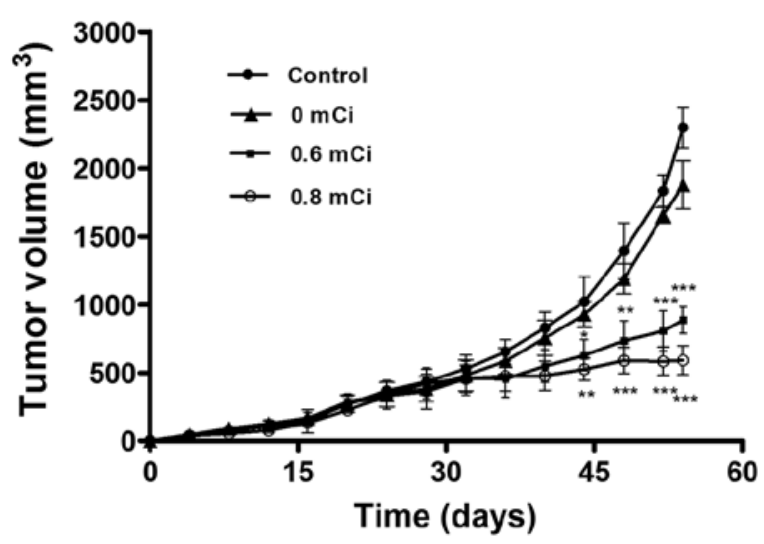

C
B

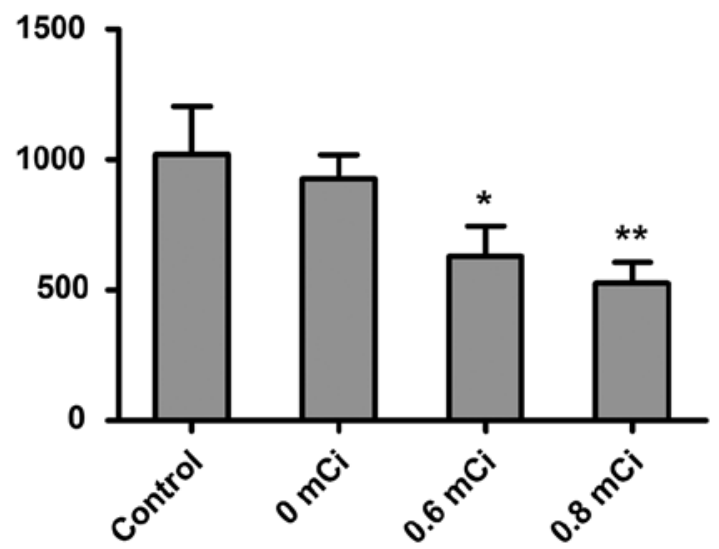

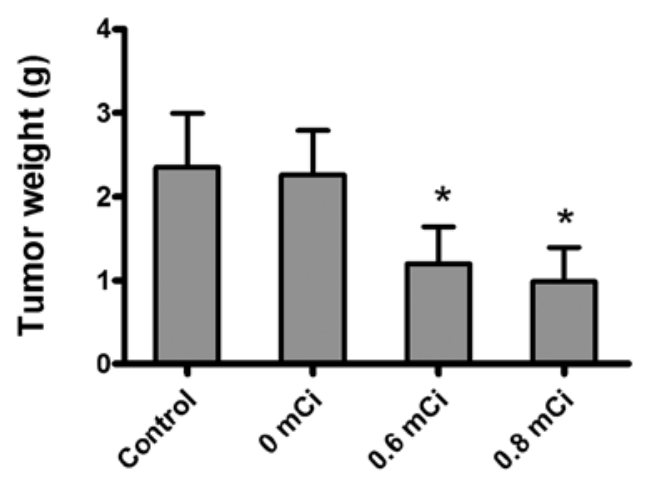

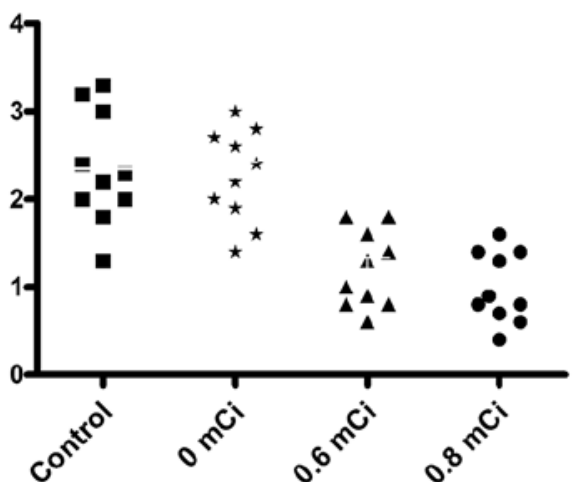

Figure 1. 125I seed irradiation suppresses tumor growth. (A) Time courses of tumor growth in control (non-implanted) mice and in seed implant mice (0, 0.6 or $0.8 \mathrm{mCi}$ seed) that were injected subcutaneously with A549 lung adenocarcinoma cells. (B) Mean tumor volumes of control and seed implant tumors on day 44. (C) Quantification of tumor weights in harvested tumors when the mouse was sacrificed. Results represent the means \pm standard error (SE); $n=10$ mice per group. ${ }^{*} \mathrm{P}<0.05,{ }^{* *} \mathrm{P}<0.01,{ }^{* * *} \mathrm{P}<0.001$ compared with control group.

Microscopic quantitative analyses of Ki67, CD34, andTUNEL. To quantify MVD, 5 random fields at x400 magnification per slide were examined for each tumor (one slide per mouse, 5 slides of each treatment group) and microvessel (MV) counts per field were done by two investigators in a blinded fashion. A single MV was defined as a cluster clearly separate from adjacent MVs or single cell stained positive for CD34 with the presence of a lumen. To quantify Ki67 expression, the number of Ki67-positive cells and the total number of tumor cells were counted in 5 random fields at $x 400$ magnification. Proliferative index was calculated by the percentage of positive cells to total tumor cells. For quantification of TUNEL positive cells, the number of TUNEL-positive and total tumor cells was counted in 5 random fields at $x 400$ magnification. The apoptosis index was calculated as the ratio of TUNEL-positive to total tumor cells. DAB-stained sections were examined via a BX51TPHD-J11 microscope (Olympus Co., Tokyo, Japan). Images were captured and analyzed using Image-Pro Plus software (Media Cybernetics, Rockville, MD, USA).

Total RNA extraction and real-time PCR. Total RNA was extracted from flash-frozen tumor tissue using TRIzol reagent (Invitrogen, Carlsbad,CA, USA) according to the manufacturer's instructions. Then $5 \mu \mathrm{g}$ of total RNA was reverse-transcribed in a $50 \mu 1$ reaction by TIANScript RT kit (Tiangen Biotech, Beijing, China). Real-time PCR was performed with Super Real PreMix Plus (Tiangen Biotech) in the ABI 7500 Real-time PCR System (Applied Biosystems, Foster City, CA, USA). The thermocycling conditions were as follows: pre-denaturation at $95^{\circ} \mathrm{C}$ for $30 \mathrm{sec}$, followed by 40 cycles at $95^{\circ} \mathrm{C}$ for $10 \mathrm{sec}, 58^{\circ} \mathrm{C}$ for $30 \mathrm{sec}$, and $70^{\circ} \mathrm{C}$ for $30 \mathrm{sec}$. We determined the expression of VEGF and HIF-1 $\alpha$ mRNAs, using the following PCR primers: for VEGF, forward 5'-GGAGCGTTCACTGTGAGC-3', reverse 5'-GCGAGTCTGTGTTTTTGC-3', and amplified fragment length of $96 \mathrm{bp}$; for HIF-1 $\alpha$, forward 5'-CTGGAAACGAGTG AAAGG-3', reverse 5'-ATGCTAAATCGGAGGGTA-3', and amplified fragment length of $86 \mathrm{bp}$; for $\beta$-actin, forward 5'-GGCACCACACCTTCTAC-3', reverse 5'-CTGGGTCATC TTTTCAC-3', and amplified fragment length of $107 \mathrm{bp}$. The housekeeping gene $\beta$-actin served as an internal control. Relative mRNA expression levels were calculated by the $2^{-\Delta \Delta C t}$ method in the ABI 7500 Sequence Detection system (Applied Biosystems), according to the manufacturer's protocol.

Protein extraction and western blotting assay. Total protein was extracted from tumor tissues with lysis buffer (Beyotime 

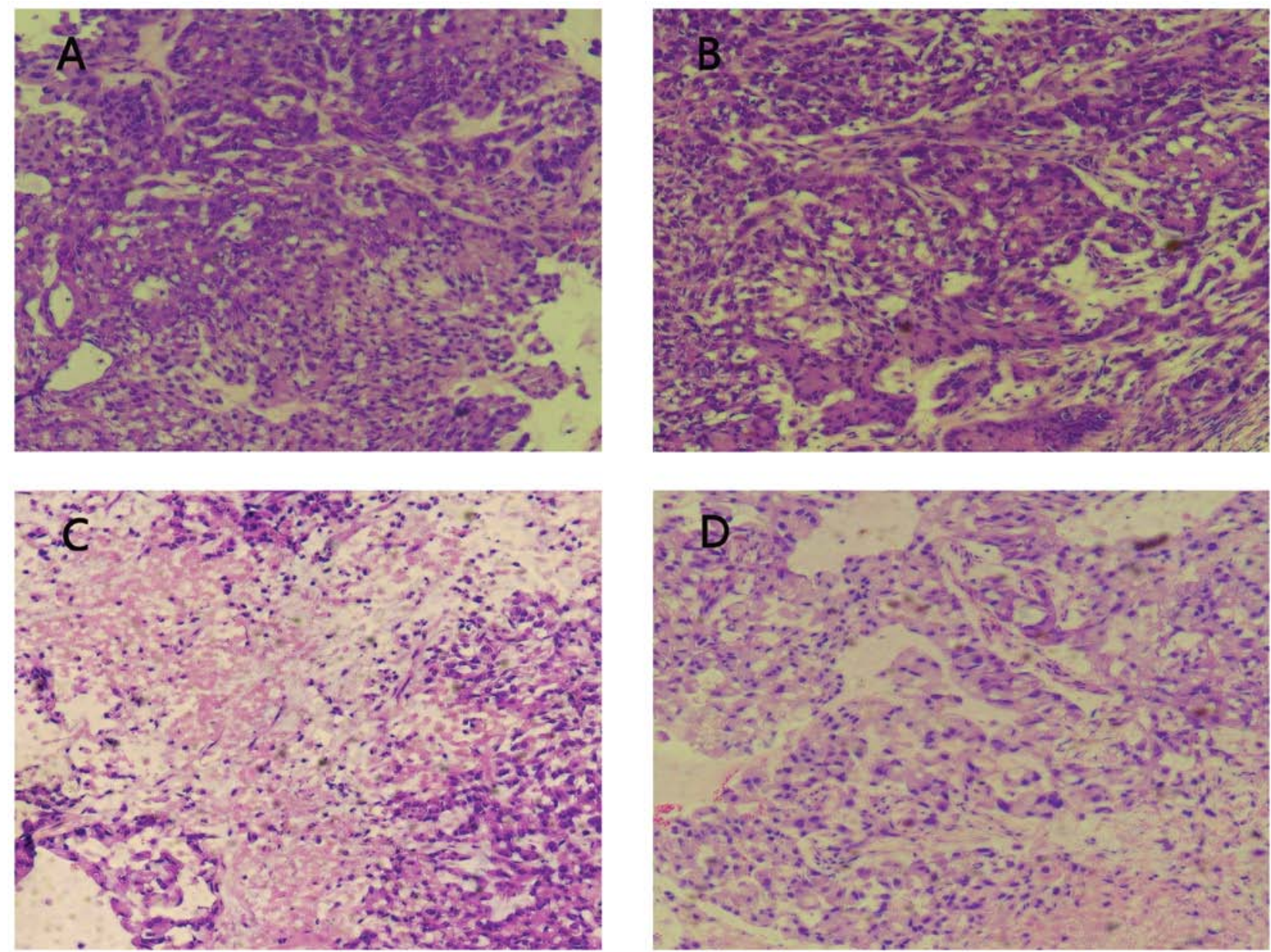

Figure 2. Pathology of 125I seed implanted lung cancer. Representative H\&E stained sections from the control (A), $0 \mathrm{mCi}(\mathrm{B}), 0.6 \mathrm{mCi}(\mathrm{C})$, and $0.8 \mathrm{mCi}(\mathrm{D})$ seed implant groups 30 days after 125I seed implantation were prepared as described in Materials and methods.

Institute of Biotechnology, Shanghai, China). The lysates were ultra-sonicated and centrifuged at $12,000 \mathrm{x}$ g at $4^{\circ} \mathrm{C}$ for $10 \mathrm{~min}$. Subsequently, the supernatant was transferred into new tubes. Protein concentrations were determined by BCA assay (Beyotime Institute of Biotechnology). Protein lysates $(20 \mu \mathrm{g})$ were then separated by $10 \%$ SDS-PAGE, and transferred to PVDF membranes. After blocking with TBS/5\% skim milk, the membranes were incubated with rabbit antimouse monoclonal anti-VEGF antibody (1:1000; Abcam) and rabbit anti-mouse monoclonal anti-HIF-1 $\alpha$ antibody (1:1000; Abcam) for $2 \mathrm{~h}$ at room temperature, respectively. They were then washed with TBST, and incubated with HRP-conjugated goat anti-rabbit IgG secondary antibodies $(1: 10,000$; CoWin Biotech, Beijing, China) for $1.5 \mathrm{~h}$ at room temperature. As a loading control, the blots were also probed with rabbit antimouse monoclonal anti- $\beta$-actin antibody (1:1,000; Abcam). Proteins were then visualized using ECl Plus Detection Reagents (Beyotime Institute of Biotechnology) with UVP GDS-8000 System (Thermo Scientific Inc., Waltham, MA, USA). Bands were quantified using ImageJ software (National Institutes of Health, Bethesda, MD, USA).

Statistical analysis. The data were obtained from at least three independent experiments and each experiment used three parallel samples. All results are presented as mean \pm standard error. Differences between means in more than two groups were analyzed by ANOVA followed by Student-NewmanKeuls test. Differences between means in two groups were compared using the unpaired-sample t-test. All statistical analyses were done using SPSS software, version 22.0 for Windows (SAS Institute, Cary, NC, USA). Differences were considered significant at $\mathrm{P}$-values $<0.05$.

\section{Results}

Effect of 125I seed irradiation on tumor growth of lung cancer. Tumor xenografts consisting of transplanted human lung adenocarcinoma A549 cells were used to evaluate the antitumor effects of the 125I seeds. When tumors reached approximately $300 \mathrm{~mm}^{3}$ at day 24 , twenty seeds with the radio dosage of 0.6 or $0.8 \mathrm{mCi}$ were implanted into mice of respective groups. In addition, to account for possibility of local effects, we also implanted sham seed with the radio dosage of $0 \mathrm{mCi}$ on a separate group of animals. All seeds were well located without loss and displacement and removed. To confirm its enhanced tumor suppression, we tested tumor growth. As shown in Fig. 1A, there were no significant changes in tumor volume during the first 3 weeks after seed implantation, but after that, tumors of 0.6 or $0.8 \mathrm{mCi}$ group were much smaller than $0 \mathrm{mCi}$ or the 
A

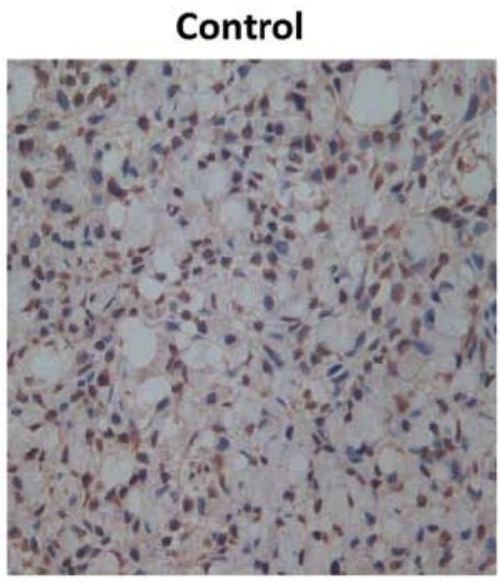

$0.6 \mathrm{mCi}$

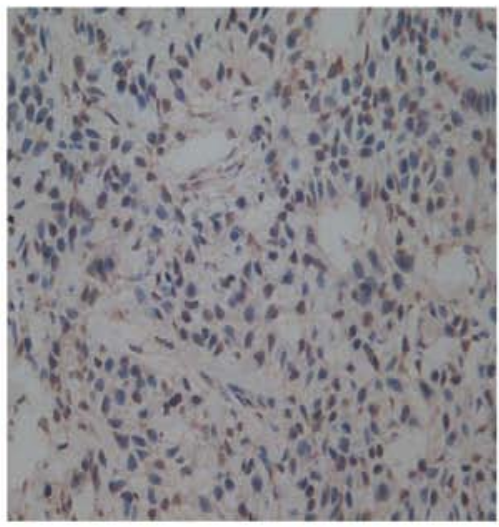

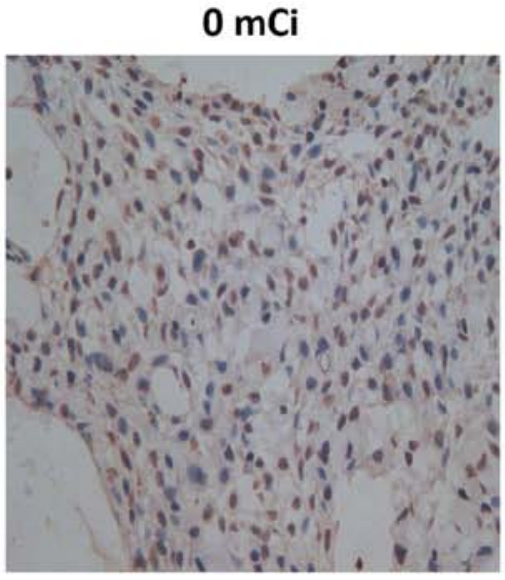

B

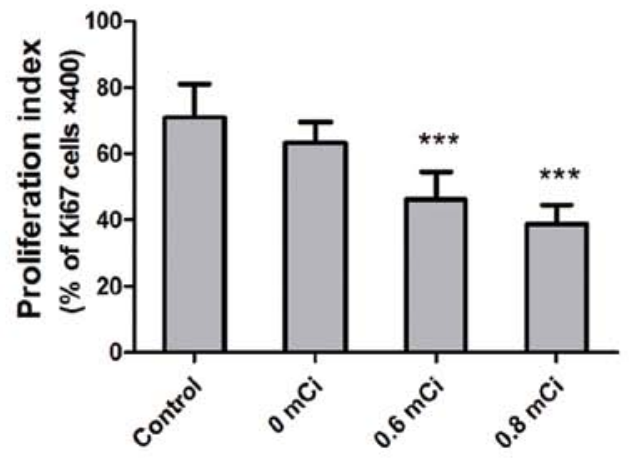

Figure 3. Proliferation in tumor tissues is decreased in lung cancer xenograft irradiated with 125I seeds. (A) Immunohistochemical images of proliferation marker Ki-67 in tumors harvested from animals. Representative sections are depicted (x400). (B) Quantification of Ki-67-positive cells as described in Materials and methods. Error bars represent SEM. ${ }^{*} \mathrm{P}<0.05,{ }^{* *} \mathrm{P}<0.01,{ }^{* * *} \mathrm{P}<0.001$ compared with control group.

control group and significant differences in tumor volumes were observed between the 0.6 or $0.8 \mathrm{mCi}$ group and the control group (all $\mathrm{P}<0.05$ ). Tumor volumes on day 44 (day 20 after treatment) in $0.6 \mathrm{mCi}(627.517 \pm 116.251)$ or $0.8 \mathrm{mCi}$ $(525.763 \pm 81.141)$ groups were significantly suppressed when compared with control group (1021.040 $\pm 183.301 ; \mathrm{P}=0.012$, $\mathrm{P}=0.006)$, with an average decrease in tumor size of about $38 \%$ or $49 \%$ (Fig. 1B). Tumor volumes in $0 \mathrm{mCi}$ or control groups increased exponentially with no regression, and no significant differences in tumor volumes were observed on day 54 between $0 \mathrm{mCi}$ and control groups $(\mathrm{P}=0.124)$. 0.6 or $0.8 \mathrm{mCi}$ group also decreased tumor weight by 49 and $62 \%$ compared with control group (all $\mathrm{P}<0.05$; Fig. $1 \mathrm{C}$ ). This indicated that $125 \mathrm{I}$ seed irradiation significantly inhibited growth of the tumors during the 4- to 5-week treatment. Besides, none of the mice died during the treatment, and no significant complications associated with seed implantation were observed in vital organs. These results underscore the safety of 125I seed treatment.

Effect of 125I seed irradiation on morphology of lung cancer. To investigate the effect of the 125I seed irradiation on the histology of the A549 xenografts, tumor sections obtained from mice in four groups were stained using $\mathrm{H} \& \mathrm{E}$. As shown in Fig. 2, the histological appearance of the tumors in $0 \mathrm{mCi}$ and control groups was quite different from that in 0.6 and $0.8 \mathrm{mCi}$ groups. In $0 \mathrm{mCi}$ and control groups, the cancer cells were densely arranged with large darkly stained nuclei and obvious karyokinesis (Fig. 2A and B). Whereas, the cancer cells around the $125 \mathrm{I}$ seed in 0.6 and $0.8 \mathrm{mCi}$ groups revealed broad necrosis after treatment (Fig. 2C and D). The cancer cells adjacent to the necrotic region were loosely arranged with condensed nuclei and reduced eosinophilic cytoplasm. These results indicated that 0.6 or $0.8 \mathrm{mCi}$ seed implantation caused growth inhibition of cancer cells in the A549 xenografts.

Effect of $125 \mathrm{I}$ seed irradiation on proliferation, MVD, and apoptosis. To determine possible mechanisms underlying 125I seed-mediated suppression of tumor growth, we hypothesized that $125 \mathrm{I}$ seed mediates its antitumor effects via inhibition of proliferation. Therefore, we first examined its anti-proliferative effects by performing Ki67 immunohistochemistry on tumors obtained at necropsy from the four groups. The results in Fig. 3A and B showed that the proliferation indices were significantly decreased in $0.6 \mathrm{mCi}(46.200 \pm 8.349)$ and $0.8 \mathrm{mCi}(38.600 \pm 6.025)$ group compared with control group $(71.000 \pm 10.000 ; \mathrm{P}<0.001$, both). However, there was no significant difference in the proliferation indices between $0 \mathrm{mCi}$ group $(63.200 \pm 6.221)$ and control group $(\mathrm{P}=0.059)$. The tumor tissues were stained with $\mathrm{CD} 34$, 
A

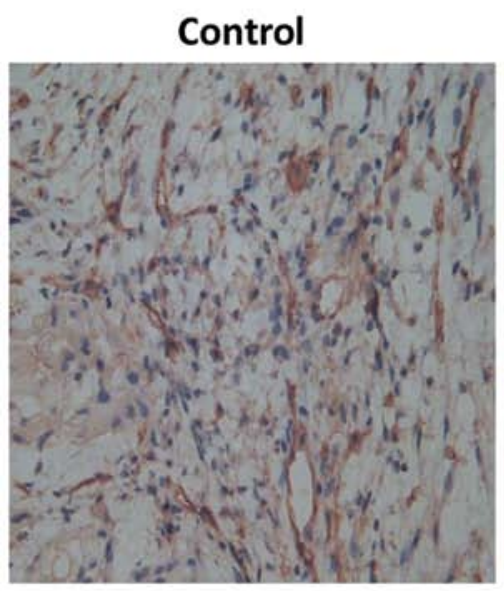

$0.6 \mathrm{mCi}$

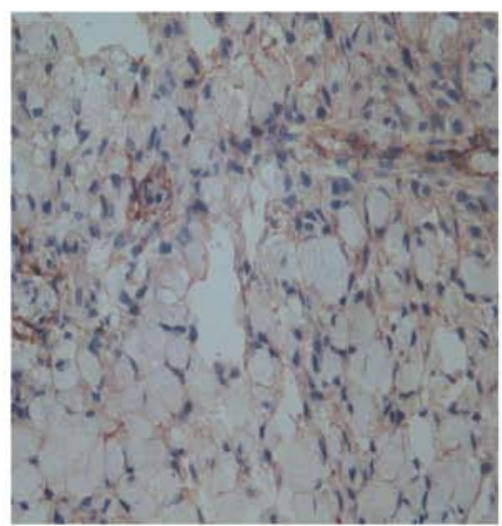

B
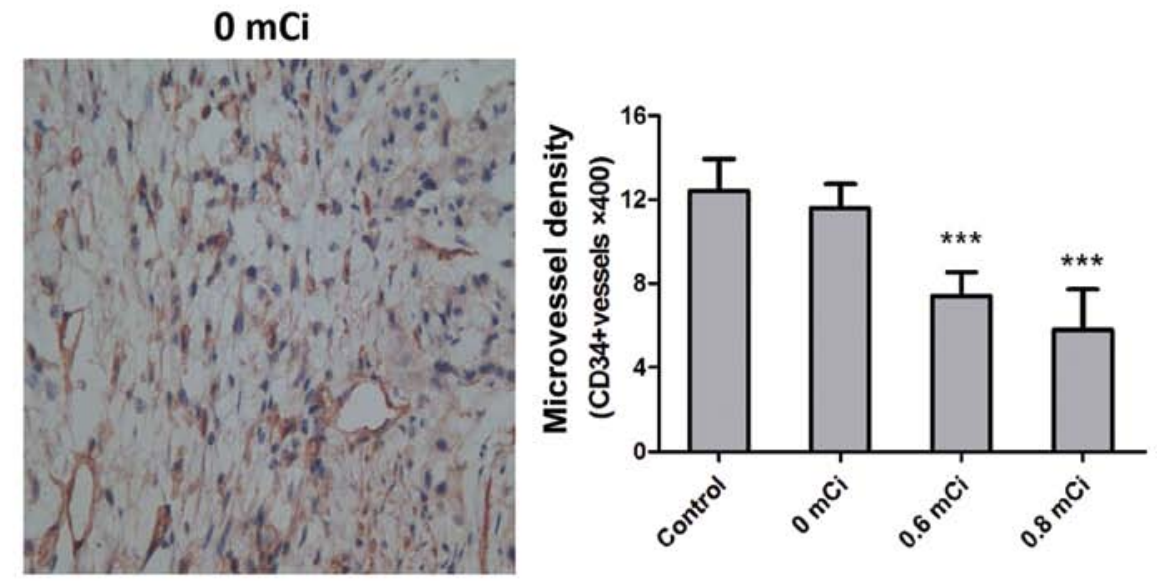

Figure 4. Angiogenesis in tumor tissues is decreased in lung cancer xenografts irradiated with 125I seeds. (A) Sections of tumors developing in nude mice were stained with anti-CD34 monoclonal antibody (x400). (B) Quantification of MVD in tumors as described in Materials and methods. Error bars represent SEM. ${ }^{*} \mathrm{P}<0.05,{ }^{* *} \mathrm{P}<0.01,{ }^{* * *} \mathrm{P}<0.001$ compared with control group.

an endothelial marker, to measure MVD and thus ascertain whether tumor angiogenesis might be affected following 125I seed therapy. MVD, calculated as a measure of angiogenesis, was significantly lower in $0.6 \mathrm{mCi}(7.400 \pm 1.140)$ and $0.8 \mathrm{mCi}(5.800 \pm 1.924)$ groups compared with control group $(12.400 \pm 1.517$; $\mathrm{P}<0.001$, both; Fig. 4A and B). Treatment with 0.6 or $0.8 \mathrm{mCi}$ seed implantation resulted in a $40 \%$ or $53 \%$ decrease in MVD compared with controls, respectively. Treatment with $0 \mathrm{mCi}(11.600 \pm 1.140)$ seed implantation did not result in a significant decrease in MVD compared with controls $(\mathrm{P}=0.366)$. To further elucidate the mechanism by which 125I seed irradiation elicits its antitumor effects, we examined tumor cell apoptosis using the TUNEL assay. As shown in Fig. 5, the apoptotic indices in control and $0 \mathrm{mCi}$ groups were $27.00 \pm 4.69 \%$ and $35.50 \pm 3.42 \%$, respectively. Further, the apoptotic indices in 0.6 and $0.8 \mathrm{mCi}$ groups were $50.00 \pm 2.58 \%$ and $62.33 \pm 4.51 \%$. There was statistically significant difference in apoptotic indices between 0.6 and $0.8 \mathrm{mCi}$ groups and control group $(\mathrm{P}<0.001$, both). These findings suggest that treatment with $125 \mathrm{I}$ seed irradiation causes apoptosis in tumor cells.

$125 I$ seed irradiation downregulates the expression of VEGF and HIF-l $\alpha$ in tumors. It has been demonstrated that a high level of HIF-1 $\alpha$ in the tumor microenvironment leads to enhanced angiogenesis and proliferation. Given that its gene target VEGF is also a critical regulator for neovascularization $(24,25)$, we questioned whether $125 \mathrm{I}$ seeds mediate its effects through modulation of HIF- $1 \alpha$ and VEGF. Therefore, we determined the HIF-1 $\alpha$ and VEGF mRNA expression by RT-PCR in A549 xenograft after treatment in all four cohorts of animals. Expression of HIF-1 $\alpha$ and VEGF mRNA in the $0.6 \mathrm{mCi}(0.370 \pm 0.086,0.279 \pm 0.066)$ and $0.8 \mathrm{mCi}$ $(0.278 \pm 0.065,0.215 \pm 0.062)$ groups were significantly lower than in the control group $(1.055 \pm 0.078,1.073 \pm 0.103$, all $\mathrm{P}<0.001$; Fig. 6A). Moreover, HIF- $1 \alpha$ and VEGF mRNA expression did not differ between $0 \mathrm{mCi}$ group $(0.810 \pm 0.006$, $0.923 \pm 0.089)$ and control group $(\mathrm{P}=0.150,0.236)$. These data suggest that $125 \mathrm{I}$ seed irradiation significantly affects the expression of HIF-1 $\alpha$ and VEGF mRNA. Expression of HIF-1 $\alpha$ and VEGF were also examined by western blotting (Fig. 6B). As shown in Fig. 6C, HIF-1 $\alpha$ and VEGF protein expression decreased in the $0.6 \mathrm{mCi}(0.554 \pm 0.0585,0.396 \pm 0.010)$ and $0.8 \mathrm{mCi}(0.502 \pm 0.0582,0.385 \pm 0.0842)$ groups compared with the control group $(0.852 \pm 0.0395,0.810 \pm 0.0593$; all $\mathrm{P}<0.001)$. However, there were no significantly statistical differences in $\mathrm{HIF}-1 \alpha$ and VEGF protein expression between $0 \mathrm{mCi}$ group $(0.810 \pm 0.006,0.923 \pm 0.089)$ and control group $(\mathrm{P}=0.157$, $\mathrm{P}=0.191)$. These data suggest that $125 \mathrm{I}$ irradiation significantly affects HIF- $1 \alpha$ and VEGF protein expression. 
A

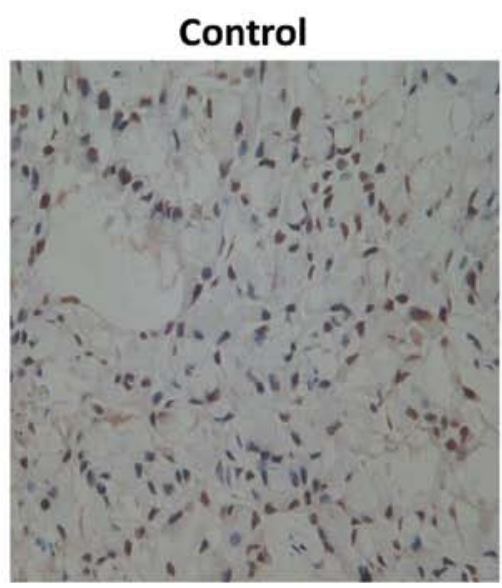

$0.6 \mathrm{mCi}$

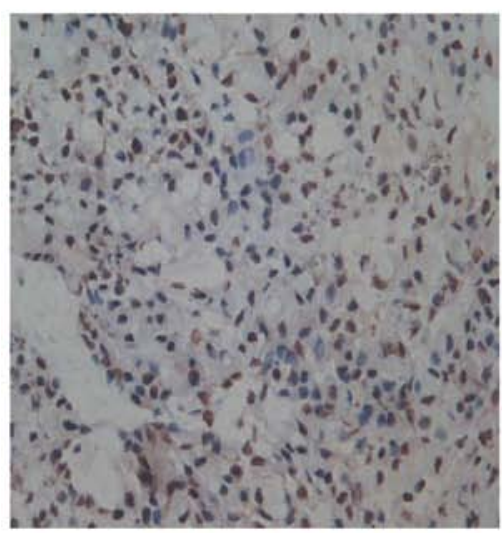

B
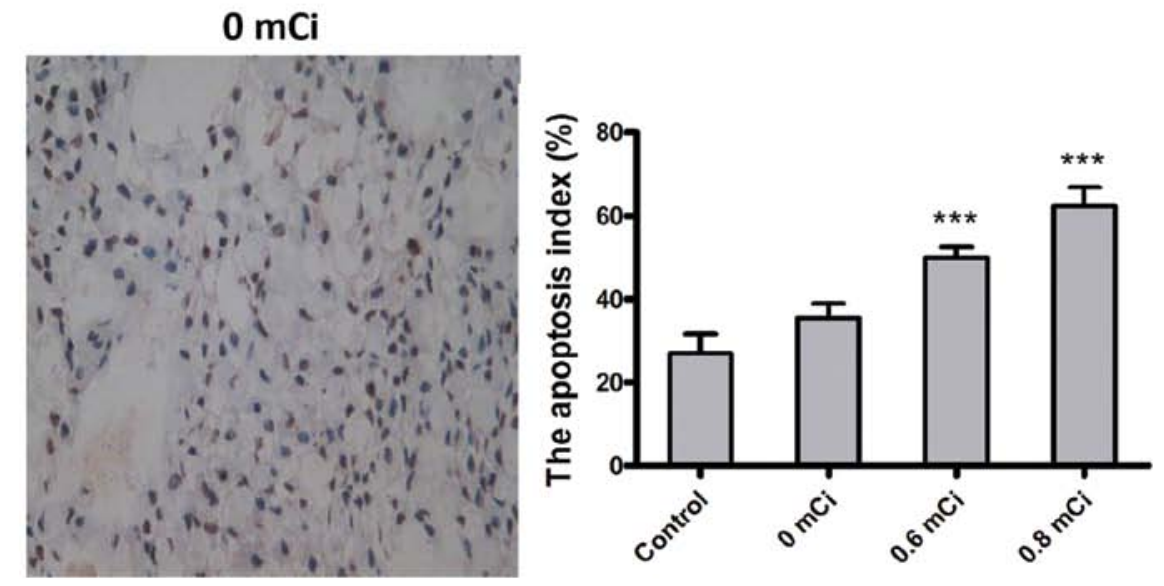

$0.8 \mathrm{mCi}$

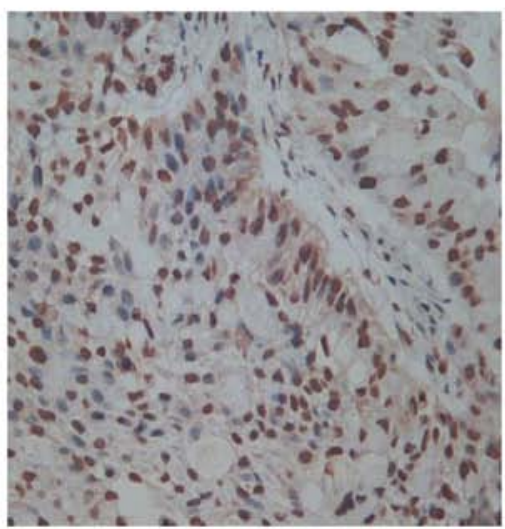

Figure 5. Apoptosis in tumor tissues is increased in lung cancer xenografts irradiated with 125I seeds. (A) Representative TUNEL staining images of tumor cells are depicted. (B) The average radio of TUNEL-positive cells in the 0.6 and $0.8 \mathrm{mCi}$ implanted groups were significantly increased over those in the control and $0 \mathrm{mCi}$ seed implanted groups (all $\mathrm{P}<0.001$ ). All images were taken at original magnification $\mathrm{x} 400$. Error bars represent $\mathrm{SEM}$. ${ }^{* * *} \mathrm{P}<0.001$ compared with control group.

\section{Discussion}

NSCLC is the most prevalent type of lung cancer. Despite therapeutics advances in surgery, chemotherapy, and radiotherapy, the five-year overall survival rate is poor. Radiotherapeutics approach has recently started to play an important role in the treatment of advanced lung cancer. However, the adverse effects of conventional EBRT on surrounding organs pose a major problem. The advantages of 125I seed radiation are the low dose rates and conformal irradiation which increases the dose applied within the target area, thus decreasing the incidental radiation injury to normal tissues and the attendant complications $(26,27)$. Several recent studies suggest that apoptosis and proliferative inhibition may have important roles in the therapeutic effects of $125 \mathrm{I}$ seeds $(18,28)$, but the mechanism in the treatment of lung cancer, especially in animal models, is not known completely. In addition, the HIF-1 $\alpha$ and VEGF may be involved in the lung cancer tumorigenesis (29). Irradiation therapy may downregulate the expression of HIF- $1 \alpha$ and VEGF in tumors, thereby affecting angiogenesis and then affecting tumor growth $(30,31)$. However, comprehensive knowledge on this topic, particularly at the molecular level, is still lacking. In this study, we assessed the radiobiological effects of 125I seeds on human lung adenocarcinoma cells in vivo.
A549 lung cancer cells were cultured ex vivo and implanted subcutaneously into the nude mice to create the animal model. We examined the effects of irradiation on tumor growth and found that radioactive $125 \mathrm{I}$ seed significantly inhibited tumor growth in nude mice. By observing H\&E-stained slides, large necrotic regions were observed around the 125I seed in tumors. Immunohistochemistry staining indicated that the expression of Ki67 and microvessel density (CD34) was inhibited by $125 \mathrm{I}$ seed irradiation in tumor tissues. The Ki67, which is a proliferative cell marker expressed in all phases of the cell cycle except the G0 stage, is considered to be a reliable index of the proliferation rate (32). Angiogenesis which is required for the delivery of oxygen and nutrients in the tumor tissues, possibly resulting in the apoptosis in vivo, was inhibited by 125I seeds. To test the effect of 125I seed radiation on apoptosis, we assayed apoptosis using TUNEL staining. Our data showed that 125I seed significantly induced apoptosis in tumor tissues, indicating that $125 \mathrm{I}$ seed may indeed inhibit tumor growth through the inhibition of angiogenesis. These data suggest that 125I seed radiation is an effective radiotherapeutics approach for lung cancer through inhibiting cell proliferation, angiogenesis and inducing apoptosis in vivo.

Hypoxia is known to be a hallmark of solid tumors and increased angiogenesis (33); under hypoxia condition, HIF-1 
A

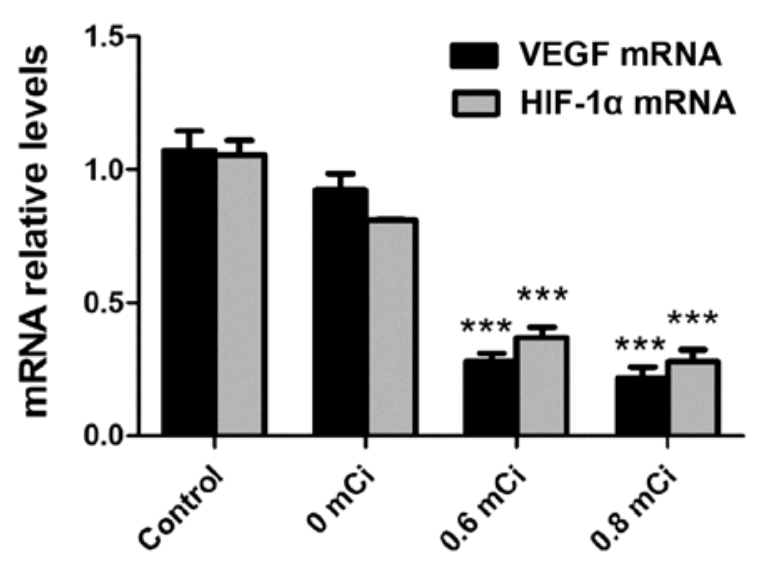

B

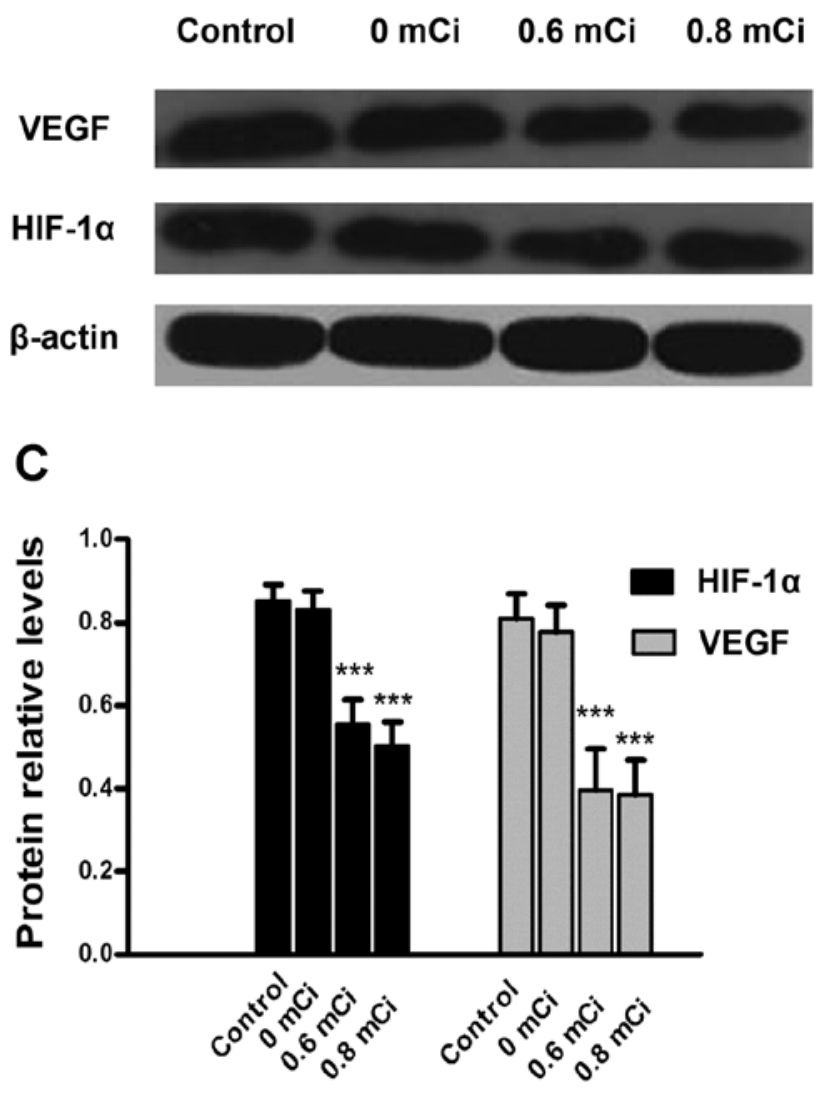

Figure 6. 125I seed irradiation downregulates HIF-1 $\alpha$ and VEGF mRNA and protein levels in lung cancer xenografts. (A) HIF-1 $\alpha$ and VEGF mRNA expression in 125 I irradiated A549 xenografts were determined by real-time PCR. (B) Representative western blots of HIF-1 $\alpha$ and VEGF proteins are shown in the upper panel. (C) Quantitative analysis of HIF-1 $\alpha$ and VEGF band optical densities. HIF-1 $\alpha$ and VEGF levels were normalized according to $\beta$-actin expression. Error bars represent SEM. ${ }^{* * *} \mathrm{P}<0.001$ compared with control group.

regulates expression of numerous angiogenic genes and stimulate angiogenesis as a long-term solution to the hypoxic conditions $(34,35)$. HIF-1 is a heterodimeric transcription factor consisted of HIF- $1 \alpha$ and HIF-1 $\beta$ subunits (36). HIF-1 $\alpha$ is an important mediator induced by hypoxia, growth factors, and oncogenes (37). As a transcription factor involved in the process of gene related hypoxic adaptation of neoplasm, HIF-1 $\alpha$ is often upregulated in human cancers. HIF- $1 \alpha$ activates the transcription of many genes such as VEGF, endothelin-1, and inducible nitric oxide synthase, which are involved in vasodilation, neovascularization, and tumor metastasis (38). Many investigations have revealed that the relationships between HIF-1 $\alpha$, VEGF and angiogenesis resulted from hypoxic condition $(39,40)$. To test whether 125 I seed radiation affects HIF-1 $\alpha$ levels, we analyzed HIF-1 $\alpha$ expression by real-time PCR and western blotting and showed that $125 \mathrm{I}$ seed specifically inhibited HIF-1 $\alpha$ expression in cancer cells.

VEGF is known to be an important angiogenic factor for endothelial cells. Many studies recently showed that VEGF levels correspond with advanced lung cancer. The increased VEGF levels were found to be associated with poor prognosis in patients with NSCLC $(41,42)$. In addition, the activation of VEGF expression can be induced by HIF-1 $\alpha$, as indicated above. Our data showed that $125 \mathrm{I}$ seed radiation inhibited VEGF expression at the transcriptional level and protein level. HIF-1 expression is known to play an important role in VEGF transcriptional activation in response to hypoxia (34). Thus, 125I seed radiation may inhibit VEGF transcriptional level through the decrease of HIF-1 expression in cancer cells. This result is consistent with the data showing the inhibition of angiogenesis by $125 \mathrm{I}$ seed because HIF- $1 \alpha$ and VEGF are important for tumor angiogenesis. Our study demonstrated that HIF-1 $\alpha$ and VEGF play an important role in the therapeutic effects of continuous low-energy $125 \mathrm{I}$ irradiation and are involved in the mechanism of the 125I seed implantation therapy process.

Collectively, it was shown that 125 I seed radiation can elicit significant anticancer effects by inhibiting proliferation and inducing apoptosis in vivo. In the tumor microenvironment, reducing the levels of HIF-1 $\alpha$ and VEGF induced by 125 I seed might inhibit angiogenesis. These findings suggest that the 125I seed radiation may be a promising therapeutics approach against lung cancer.

\section{References}

1. McGuire S: World Cancer Report 2014. Geneva, Switzerland: World Health Organization, International Agency for Research on Cancer, WHO Press, 2015. Adv Nutr 7: 418-419, 2016.

2. Chen W, Zheng R, Zeng H, Zhang S and He J: Annual report on status of cancer in China, 2011. Chin J Cancer Res 27: 2-12, 2015. 
3. Toyokawa G, Takenoyama M and Ichinose Y: Multimodality treatment with surgery for locally advanced non-small-cell lung cancer with $\mathrm{n} 2$ disease: A review article. Clin Lung Cancer 16 : 6-14, 2015

4. Cardenal F, Nadal E, Jové M and Faivre-Finn C: Concurrent systemic therapy with radiotherapy for the treatment of poor-risk patients with unresectable stage III non-small-cell lung cancer: A review of the literature. Ann Oncol 26: 278-288, 2015.

5. Pfister DG, Johnson DH, Azzoli CG, Sause W, Smith TJ, Baker S Jr, Olak J, Stover D, Strawn JR, Turrisi AT, et al; American Society of Clinical Oncology: American Society of Clinical Oncology treatment of unresectable non-small-cell lung cancer guideline: Update 2003. J Clin Oncol 22: 330-353, 2004.

6. Dillman RO, Hemdon J, Seagren SL, Eaton WL Jr and Green MR Improved survival in stage III non-small-cell lung cancer sevenyear follow-up of cancer and leukemia group B (CALGB) 8433 trial. J Natl Cancer Inst 88: 1210-1215, 1996.

7. Wagner TD and Yang GY: The role of chemotherapy and radiation in the treatment of locally advanced non-small cell lung cancer (NSCLC). Curr Drug Targets 11: 67-73, 2010.

8. Liew MS, Sia J, Starmans MH, Tafreshi A, Harris S, Feigen M, White S, Zimet A, Lambin P, Boutros PC, et al: Comparison of toxicity and outcomes of concurrent radiotherapy with carboplatin/paclitaxel or cisplatin/etoposide in stage III non-small cell lung cancer. Cancer Med 2: 916-924, 2013.

9. Cannon DM, Mehta MP, Adkison JB, Khuntia D, Traynor AM, Tomé WA, Chappell RJ, Tolakanahalli R, Mohindra P Bentzen SM, et al: Dose-limiting toxicity after hypofractionated dose-escalated radiotherapy in non-small-cell lung cancer. J Clin Oncol 31: 4343-4348, 2013

10. Park DS, Gong IH, Choi DK, Hwang JH, Shin HS and Oh JJ: Radical prostatectomy versus high dose permanent prostate brachytherapy using iodine-125 seeds for patients with high risk prostate cancer: A matched cohort analysis. World J Urol 31: $1511-1517,2013$

11. Wang ZM, Lu J, Liu T, Chen KM, Huang G and Liu FJ: CT-guided interstitial brachytherapy of inoperable non-small cell lung cancer. Lung Cancer 74: 253-257, 2011.

12. Joyce F, Burcharth F, Holm HH and Strøyer I: Ultrasonically guided percutaneous implantation of iodine-125 seeds in pancreatic caicinoma. Int J Radiat Oncol Biol Phys 19: 1049-1052, 1990.

13. Wang JJ, Yuan HS, Li JN, Jiang WJ, Jiang YL and Tian SQ: Interstitial permanent implantation of $125 \mathrm{I}$ seeds as salvage therapy for re-recurrent rectal carcinoma. Int J Colorectal Dis 24: 391-399, 2009

14. Jiang Y-L, Meng N, Wang J-J, Ran WQ, Yuan HS, Qu A and Yang RJ: Percutaneous computed tomography/ultrasonographyguided permanent iodine-125 implantation as salvage therapy for recurrent squamous cell cancers of head and neck. Cancer Biol Ther 9: 959-966, 2010.

15. Zhang FJ, Li CX, Zhang L, Wu PH, Jiao DC and Duan GF: Shortto mid-term evaluation of CT-guided 125I brachytherapy on intra-hepatic recurrent tumors and/or extra-hepatic metastases after liver transplantation for hepatocellular carcinoma. Cancer Biol Ther 8: 585-590, 2009.

16. Heelan RT, Hilaris BS, Anderson LL, Nori D, Martini N, Watson RC, Caravelli JF and Linares LA: Lung tumors: Percutaneous implantation of I-125 sources with CT treatment planning. Radiology 164: 735-740, 1987.

17. Li W, Guan J, Yang L, Zheng X, Yu Y and Jiang J: Iodine-125 brachytherapy improved overall survival of patients with inoperable stage III/IV non-small cell lung cancer versus the conventional radiotherapy. Med Oncol 32: 395, 2015.

18. Qu A, Wang H, Li J, Wang J, Liu J, Hou Y, Huang L and Zhao Y: Biological effects of (125)i seeds radiation on A549 lung cancer cells: G2/M arrest and enhanced cell death. Cancer Invest 32: 209-217, 2014

19. Takabayashi K, Kashiwagi K, Kawata T, Sato T, Matsuoka K, Hisamatsu T, Takaishi H, Hibi T, Ogata H, Yahagi N, et al: Continuous low-dose irradiation by I-125 seeds induces apoptosis of gastric cancer cells regardless of histological origin. Cancer Biol Ther 15: 81-88, 2014.

20. Carmeliet P: Manipulating angiogenesis in medicine. J Intern Med 255: 538-561, 2004.
21. Acker T and Plate KH: A role for hypoxia and hypoxia-inducible transcription factors in tumor physiology. J Mol Med (Berl) 80: $562-575,2002$.

22. Folkman J: Tumor angiogenesis: Therapeutic implications. $\mathrm{N}$ Engl J Med 285: 1182-1186, 1971.

23. Lee JW, Shahzad MM, Lin YG, Armaiz-Pena G, Mangala LS, Han HD, Kim HS, Nam EJ, Jennings NB, Halder J, et al: Surgical stress promotes tumor growth in ovarian carcinoma. Clin Cancer Res 15: 2695-2702, 2009.

24. Hong S-S, Lee H and Kim K-W: HIF-1 $\alpha$ : A valid therapeutic target for tumor therapy. Cancer Res Treat 36: 343-353, 2004.

25. Thangarajah H, Yao D, Chang EI, Shi Y, Jazayeri L, Vial IN, Galiano RD, Du XL, Grogan R, Galvez MG, et al: The molecular basis for impaired hypoxia-induced VEGF expression in diabetic tissues. Proc Natl Acad Sci USA 106: 13505-13510, 2009.

26. Peretz T, Nori D, Hilaris B, Manolatos S, Linares L, Harrison L, Anderson LL, Fuks Z and Brennan MF: Treatment of primary unresectable carcinoma of the pancreas with I-125 implantation. Int J Radiat Oncol Biol Phys 17: 931-935, 1989.

27. Mazeron JJ, Noël G, Simon JM, Racadot S and Jauffret E: Brachytherapy in head and neck cancers. Cancer Radiother 7: 62-72, 2003 (In French).

28. Yu L, Chen $\mathrm{H}$ and Cheng W: Influence of $\sim(125) \mathrm{I}$ continuous low dose-rate irradiation to apoptosis and DNA-PK expression of human lung carcinoma cell lines. Chinese J Clin Med 6: 2007.

29. Lin X, Li HR, Lin XF, Yu ME, Tu XW, Hua ZD, Lin M, Xu NL, Han LL and Chen YS: Silencing of Livin inhibits tumorigenesis and metastasis via VEGF and MMPs pathway in lung cancer. Int J Oncol 47: 657-667, 2015.

30. Semenza GL: Targeting HIF-1 for cancer therapy. Nat Rev Cancer 3: 721-732, 2003.

31. Aita M, Fasola G, Defferrari C, Brianti A, Bello MG, Follador A, Sinaccio G, Pronzato $\mathrm{P}$ and Grossi F: Targeting the VEGF pathway: Antiangiogenic strategies in the treatment of non-small cell lung cancer. Crit Rev Oncol Hematol 68: 183-196, 2008.

32. Gerdes J, Lemke H, Baisch H, Wacker HH, Schwab U and Stein H: Cell cycle analysis of a cell proliferation-associated human nuclear antigen defined by the monoclonal antibody Ki-67. J Immunol 133: 1710-1715, 1984.

33. Semenza GL: Involvement of hypoxia-inducible factor 1 in human cancer. Intern Med 41: 79-83, 2002.

34. Forsythe JA, Jiang BH, Iyer NV, Agani F, Leung SW, Koos RD and Semenza GL: Activation of vascular endothelial growth factor gene transcription by hypoxia-inducible factor 1 . Mol Cell Biol 16: 4604-4613, 1996.

35. Semenza GL: Hypoxia-inducible factor 1: Master regulator of $\mathrm{O}_{2}$ homeostasis. Curr Opin Genet Dev 8: 588-594, 1998.

36. Wang GL, Jiang BH, Rue EA and Semenza GL: Hypoxiainducible factor 1 is a basic-helix-loop-helix-PAS heterodimer regulated by cellular $\mathrm{O}_{2}$ tension. Proc Natl Acad Sci USA 92: 5510-5514, 1995

37. Fukuda R, Hirota K, Fan F, Jung YD, Ellis LM and Semenza GL: Insulin-like growth factor 1 induces hypoxia-inducible factor 1-mediated vascular endothelial growth factor expression, which is dependent on MAP kinase and phosphatidylinositol 3-kinase signaling in colon cancer cells. J Biol Chem 277: 3820538211, 2002.

38. Kerbel RS: New targets, drugs, and approaches for the treatment of cancer: An overview. Cancer Metastasis Rev 17: 145-147, 1998.

39. Mouriaux F, Sanschagrin F, Diorio C, Landreville S, Comoz F, Petit E, Bernaudin M, Rousseau AP, Bergeron D and Morcos M: Increased HIF-1 $\alpha$ expression correlates with cell proliferation and vascular markers CD31 and VEGF-A in uveal melanoma. Invest Ophthalmol Vis Sci 55: 1277-1283, 2014.

40. Harada H: How can we overcome tumor hypoxia in radiation therapy? J Radiat Res (Tokyo) 52: 545-556, 2011.

41. Iwasaki A, Kuwahara M, Yoshinaga Y and Shirakusa T: Basic fibroblast growth factor (bFGF) and vascular endothelial growth factor (VEGF) levels, as prognostic indicators in NSCLC. Eur J Cardiothorac Surg 25: 443-448, 2004.

42. Kishiro I, Kato S, Fuse D, Yoshida T, Machida S and Kaneko N Clinical significance of vascular endothelial growth factor in patients with primary lung cancer. Respirology 7: 93-98, 2002. 